\title{
https://doi.org/10.46813/2020-130-131 \\ EMISSION SPECTRA AND CURRENT CHARACTERISTICS OF NEGATIVE CORONA DISCHARGE IN AN ELECTRODE SYSTEM WITH LIQUID ANODE
}

\author{
O.V. Bolotov, V.I. Golota, G.V. Taran \\ NSC “Kharkov Institute of Physics and Technology", Kharkiv, Ukraine \\ E-mail: bolotov@kipt.kharkov.ua
}

\begin{abstract}
Experimental study of emission spectra and current characteristics of negative corona discharge over the surface of aqueous salt solutions have been carried out. The radiation spectra from the active zone of the discharge in the wavelength range $200 \ldots 600 \mathrm{~nm}$ were obtained and identified. It was found that most of the spectral lines correspond to the lines of second positive system of molecular nitrogen. The spectral lines of the nitrogen ion $\mathrm{N}_{2}{ }^{+}$and the lines corresponding to the emission of the $\mathrm{OH}$ radical in the UV spectral region are also observed. Current-voltage characteristics of the discharge were obtained at the non-stationary and diffuse stages of the discharge. It was shown that obtained current-voltage characteristics are in good agreement with the results of theoretical calculations using the Townsend expression.
\end{abstract}

PACS: 52.80.Hc

\section{INTRODUCTION}

Investigations of atmospheric pressure gas discharges have been of considerable interest lately, since low-temperature plasma of gas discharge has unique characteristics, which makes it possible to use a gas discharge in modern plasma-chemical technologies. Such plasma-chemical technologies as ozone synthesis [1], electric filters for cleaning gases from aerosol particles, as well as technologies associated with the plasmachemical treatment of liquid substances with contact plasma [2] are especially widespread. Most technologies use atmospheric pressure corona discharge in a strongly inhomogeneous electric field, which is due to the unique properties of nonequilibrium gas discharge plasma. In a low-temperature plasma, when the average energy of electrons exceeds the thermal energy by an order of magnitude, due to the excitation of the vibrational levels of molecules, it is possible to increase the rate of chemical reactions. That significantly reduces the energy consumption for the production of the final reaction product. By optimizing the burning mode of the discharge, it is possible to prevent the transition of the discharge to the spark. Also we can significantly reduce the energy consumption in the discharge by reducing the energy consumption for ion heating of the gas. One of such discharges is a corona discharge in a "needle-to-plane" electrode system. In particular, corona discharge in an electrode system with a needle-shaped metal anode and a liquid cathode is used in technologies for disinfection and purification of aqueous solutions. Also it is used in technologies involving a change in the chemical composition of liquid substances by discharge plasma treatment. There are also known about study of a pulsed streamer discharge for the effective purification of wastewater from phenol [3]. The high efficiency of corona discharge in plasma-chemical technologies for disinfection of aqueous solutions is primarily due to the high concentration of chemically active particles and free radicals generated in non-equilibrium gas-discharge plasma. The generation of chemically active particles with a high oxidizing potential in the discharge, such as atomic oxygen $\mathrm{O}$ and hydroxyl radical $\mathrm{OH}$, makes it possible to effectively use this type of discharge for disinfection tasks. First of all, good efficiency is associated with the high rate of chemical reactions of these particles with impurities dissolved in water. Diagnostics and analysis of gas-discharge plasma radiation in the optical wavelength range allows to control the production of chemically active particles. Investigation of the emission spectra of discharge radiation can provide information on the production of certain types of active particles in the discharge, in particular, on the synthesis of the hydroxyl radical $\mathrm{OH}$. Thereby, experimental study of the emission spectra and current characteristics of a corona discharge at various stages of burning are of interest, since make it possible to determine the modes and conditions of discharge burning under which the effective production of chemically active particles occurs. In this work, we experimentally investigated the emission spectra of radiation from the active zone of the negative corona discharge above the liquid surface, and the current-voltage characteristics of the discharge.

\section{EXPERIMENTAL SETUP}

Experimental study of corona discharge with a liquid anode was carried out on the setup schematically shown in Fig. 1.

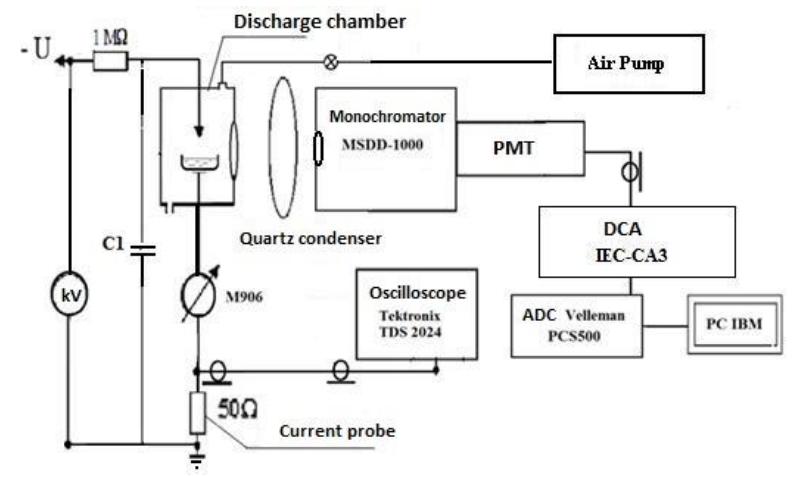

Fig. 1. Experimental setup: PMT-Hamamatsu R9110 photomultiplier tube; ADC-analog-to-digital converter; DCA - DC amplifier; C1 - capacitive voltage filter 
Stabilized adjustable high voltage power supply unit of $0 \ldots 15 \mathrm{kV}$ range was used to initiate the discharge burning. The voltage of the discharge gap was measured with a C-196 HV voltmeter. The average discharge current was measured with a microammeter. To maintain a constant voltage across the discharge gap, a highvoltage capacitor $\mathrm{C} 1$ with a capacity of $1000 \mathrm{pF}$ was connected to the electric circuit. In the experiments, an electrode system of the "needle to plane" type with a liquid anode was used. The cathode was a copper needle with a cross section of $\propto 1 \mathrm{~mm}$. The anode was a glass beaker filled with various test solutions. At the bottom of the glass, there was a metal disk with a diameter of $20 \mathrm{~mm}$, which was connected to the discharge circuit and was at ground potential. To measure the amplitudetime characteristics of the current pulses, calibrated current shunts with a nominal value of $50 \Omega$ were used. The current shunts were calibrated using a Tektronix CT-1 calibration shunt with a signal bandwidth of $25 \mathrm{kHz} . .1 \mathrm{GHz}$. A signal from the current shunts was analyzed with a digital oscilloscope Tektronix TDS2024B. The bandwidth of the oscilloscope was $200 \mathrm{Mhz}$, sampling frequency - $1 \mathrm{Gs} / \mathrm{s}$. The working gas was injected into the discharge chamber using an AirPump air membrane compressor; the gas flow rate was measured with a rotameter and was $21 / \mathrm{min}$. In all experiments laboratory air was used as the working gas. Spectroscopic study of the discharge was carried out at optical stand based on a double-dispersion monochromator-spectrograph "Solar-Tii" MSDD-1000. To reach high spectral resolution, a double diffraction grating of 2.400 grooves $/ \mathrm{mm}$ with a linear dispersion of $0.41 \mathrm{~nm} / \mathrm{mm}$ was used. The emission spectra of the discharge in the wavelength range $200 \ldots 600 \mathrm{~nm}$ were registered through the quartz window of the discharge chamber. The registration of radiation from active zone of the discharge gap was carried out with a help of a slits system. On the output slit of the monochromator, a high-speed photomultiplier tube Hamamatsu R-9110 was installed. PMT characteristics: spectral sensitivity range of $185 \ldots 900 \mathrm{~nm}$, signal pulse rise time $2.2 \mathrm{~ns}$. The signal from the PMT was transferred to the input of the DC amplifier IEC-CA3, which has the following characteristics: range of the conversion factor $\mathrm{k}-\left(10^{-10} \ldots 10^{-5}\right) \mathrm{A} / \mathrm{V}$, the amplitude of the internal noise - not more than $1 \mathrm{pA}$, thermal drift of the output voltage - not more than $0.15 \mathrm{mV} / \mathrm{deg}$. The signal from the amplifier was transferred to the input $(1 \mathrm{M} \Omega$ ) of the Velleman PCS 500 ADC, which was connected to a computer. The PC-Lab2000 software package allowed to display digitized data (visualize the spectrum) from the ADC on a computer monitor in real-time graphical mode, and also to record digitized data.

\section{EXPERIMENTAL RESULTS}

When studying a negative corona discharge in a highly inhomogeneous electric field, it is well known that the discharge can burn in two stages [4]. At the initial stage of the discharge, starting from the ignition voltage, the discharge burns in non-stationary (pulsed) stage, which is characterized by a stable sequence of Trichel current pulses [5]. After reaching a certain volt- age on the discharge gap, the discharge passes into the diffuse stage [6]. Diffuse stage is characterized by the DC current through the discharge gap and low gas temperature in the discharge [7]. Trichel pulsed mode of a corona discharge at atmospheric pressure is an example of a self-maintained gas discharge in an electronegative gas. Pulsed stage occurs only under conditions when the attachment of electrons to electronegative gas molecules plays a significant role in the dynamics of charged particles.

\subsection{THE CURRENT-VOLTAGE CHARACTERISTIC'S OF NEGATIVE CORONA DISCHARGE WITH LIQUID ANODE}

Taking into account the processes of electron attachment to gas molecules with the formation of negative ions in the discharge gap, the number of electrons $\mathrm{n}_{\mathrm{e}}$ decreases, while the number of negative ions $\mathrm{n}$ increases. With a fixed value of the electric field strength in the discharge gap, we have:

$$
\begin{aligned}
& \frac{d n_{e}}{d z}=(\alpha-a) n_{e}, \\
& \frac{d n_{-}}{d z}=a n_{e},
\end{aligned}
$$

where $\alpha$ is the ionization coefficient, $a$ is the electron attachment coefficient.

If we integrate the system of equations (1), (2) from 0 to $h$, where $h$ is a given distance along the discharge gap, and take $n_{e}(0)=n_{0}$, then

$$
\begin{aligned}
& n_{e}=n_{o} \exp [(\alpha-a) h], \\
& n_{-}=n_{o} \frac{a}{\alpha-a}\{\exp [(\alpha-a) h]-1\} .
\end{aligned}
$$

For the total current, we obtain the following expresion:

$$
i=i_{0}\left\{\frac{\alpha}{\alpha-a} \exp [(\alpha-a) h]-\frac{a}{\alpha-a}\right\} .
$$

For $a \longrightarrow 0$ from expression (5) we obtain the dependence

$$
i=i_{0} \exp (\alpha h) \text {, }
$$

which describes the avalanche multiplication of electrons. If we take into account the attachment of electrons to electronegative gas molecules, then this leads to a decrease in the rate of electron multiplication, and the formation of a negative space charge in the discharge gap. This space charge strongly shields the external electric field near the needle cathode, and the discharge current becomes limited. Further relaxation of the negative space charge at the anode leads to the resumption of conditions for the onset of a next current pulse. This process leads to the establishment of a certain sequence of Trichel current pulses, the characteristics of which are mainly determined by the value of the effective voltage on the discharge gap.

The current-voltage characteristics of the negative corona with a liquid anode was investigated at $d=7 \mathrm{~mm}$ discharge gap. In experiments, various aqueous solutions of water-soluble salts were used. The main characteristics of aqueous solutions of salts used in the experiments are shown in Table. All solutions were prepared 
on the basis of distilled water. Solutions were prepared with the same concentration $\mathrm{C}=10 \mathrm{~g} / \mathrm{l}$.

Conductivity of aqueous solutions of salts

\begin{tabular}{|c|l|c|}
\hline № & \multicolumn{1}{|c|}{ Aqueous solution } & $\begin{array}{c}\text { Conductivity, } \\
\mu \mathrm{S} / \mathrm{cm}\end{array}$ \\
\hline 1 & Distilled water $\mathrm{H}_{2} \mathrm{O}$ & 1.96 \\
\hline 2 & $\begin{array}{l}\text { Copper sulphate } \\
\mathrm{CuSO}_{4}\end{array}$ & 4490 \\
\hline 3 & $\begin{array}{l}\mathrm{Sodium} \\
\mathrm{Na}_{2} \mathrm{WO}_{4}\end{array}$ & 6520 \\
\hline 4 & $\begin{array}{l}\mathrm{Cobalt} \text { chloride } \\
\mathrm{CoCl}_{2}\end{array}$ & 14970 \\
\hline 5 & $\begin{array}{l}\mathrm{Zinc}_{2} \text { chloride } \\
\mathrm{ZnCl}_{2}\end{array}$ & \\
\hline
\end{tabular}

In Fig. 2 below, the current-voltage characteristics of a negative corona with a liquid anode for various solutions are shown, as well as the obtained theoretical calculations. All curves show two stages of discharge burning: 1) non-stationary stage (Trichel pulse mode), 2) diffuse stage of burning.

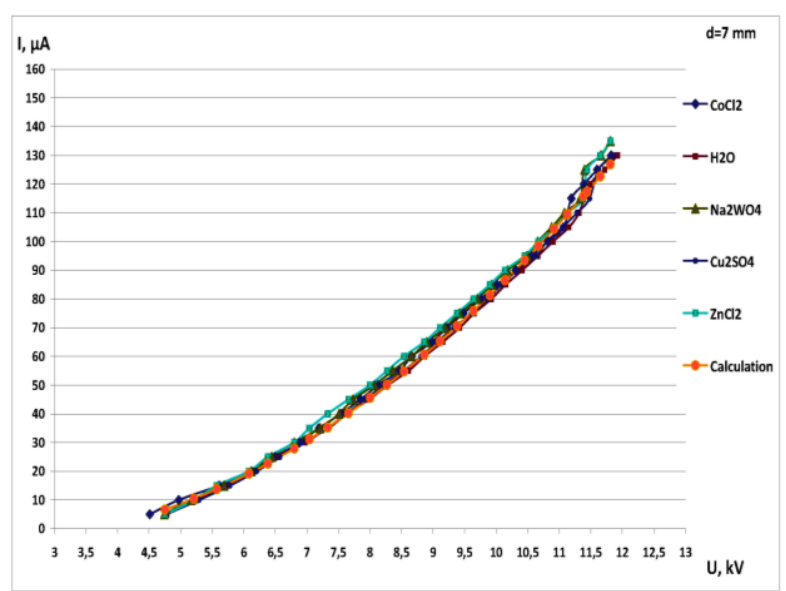

Fig. 2. Current-voltage characteristics of negative corona discharge with a liquid anode at $d=7 \mathrm{~mm}$ discharge gap. Aqueous solutions of salts.

The concentration of aqueous solutions $C=10 \mathrm{~g} / \mathrm{l}$

The current-voltage characteristics of discharge shown in Fig. 2 correspond to the Townsend type current-voltage characteristics of the corona discharge, which obey the following dependence of the current on the voltage [8]:

$$
I=A \cdot U \cdot\left(U-U_{o}\right),
$$

where $I$ is the discharge current, $U$ is the operating voltage, $U_{0}$ is the discharge onset voltage, $A$ is a constant depending on the properties of the gas and the geometric factors of the electrode system.

The current-voltage characteristic of corona discharge is determined by two constants $A$ and $U_{0}$, which are the parameters of dependence (7). The theoretical calculation of the current-voltage characteristic was carried out using dependence (7) taking into account the value of the discharge ignition voltage $U_{0}=3.7 \mathrm{kV}$. Coefficient $A$ was a free parameter. Fig. 2 shows a good agreement of the obtained current-voltage characteristics with the calculation results according to relation (7).
It was found that regardless of the value of solutions conductivity, the type of ions, in a fixed discharge gap, the current-voltage characteristics of the discharge practically identical. This may indicate that the conductivity of the solution does not have strong influence on the processes occurring in the discharge, both in the active zone and in the drift zone, which mainly determine the average discharge current. It is possible that the conductivity of the solutions is responsible only for the transfer of the discharge current.

\subsection{ELECTRODYNAMIC CHARACTERISTICS OF THE DISCHARGE. TRICHEL PULSE MODE}

For a more detailed study of the electrodynamic characteristics of the discharge the waveforms of discharge current pulses were registered with an oscilloscope. The amplitude-time and frequency characteristics of the discharge current pulses were obtained.

In the experiments, discharge burning was maintained in the Trichel pulse mode. An oscilloscope, in the "On line" mode, monitoring the waveforms of discharge current pulses. It makes possible to observe the stability of the discharge burning process. For comparison, two liquids were studied: distilled water and an aqueous solution of cobalt chloride $\mathrm{CoCl}_{2}$ with a concentration of $10 \mathrm{~g} / \mathrm{l}$. In Fig. 3 below waveforms of the Trichel pulse sequence are shown. The waveforms were obtained during the burning of the discharge above the surface of the liquids under study.

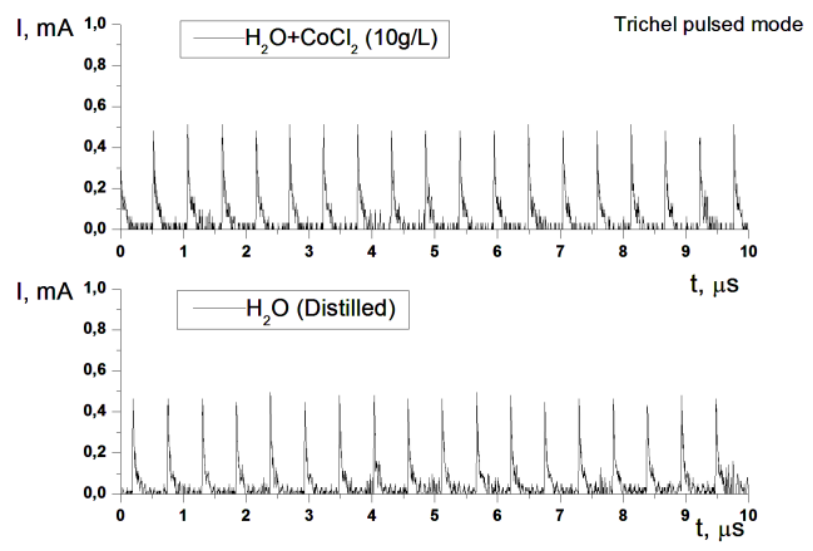

Fig. 3. Waveforms of Trichel current pulses for different liquid anodes.

1) Distilled water. Applied voltage $U=9.65 \mathrm{kV}$, average discharge current $I=65 \mu A$, discharge current pulse repetition rate $f=1.7 \mathrm{MHz}$.

2) Aqueous solution of cobalt chloride.

$U=9.66 \mathrm{kV}, I=80 \mu \mathrm{A}, f=1.79 \mathrm{MHz}$

From the above waveforms, it can be noted that at a fixed applied voltage, one can observe similar amplitude-frequency characteristics of Trichel pulses for discharges over the surface of various liquids. For distilled water and for aqueous solution of cobalt chloride, a similarity in the current characteristics of the discharge is observed. The amplitude of the discharge current pulses (I $\sim 0.5 \mathrm{~mA}$ ) is similar in magnitude. Also it can be noted that the values of the current pulse repetition rate 
(f $\sim 1.7 \mathrm{MHz}$ ) is similar. Moreover, the differences in the values of electric conductivity of these solutions are quite large. This may indicate that the conductivity of the solution does not affect the mechanism of establishing the sequence of Trichel current pulses, and does not significantly affect the processes occurring in the active and drift zones of the discharge gap.

\subsection{EMISSION SPECTRA FROM THE ACTIVE ZONE OF THE NEGATIVE CORONA DISCHARGE IN AIR. DISCHARGE WITH A LIQUID ANODE}

As a result of the investigations carried out, the emission spectra were obtained from the near-cathode region $(\sim 1 \mathrm{~mm}$ from the surface of the needle electrode). The spectra were recorded in the wavelength range $200 \ldots 600 \mathrm{~nm}$. The emission spectra were obtained during the discharge burning in the Trichel pulse mode. An aqueous solution of sodium chloride $\mathrm{NaCl}$ with a concentration of $10 \mathrm{~g} / \mathrm{l}$ was used as a liquid electrode. Solution characteristics: conductivity $\mathrm{EC}=16850 \mu \mathrm{S} / \mathrm{cm}$. The applied voltage was kept constant and equal to $\mathrm{U}=9.5 \mathrm{kV}$, the average discharge current $\mathrm{I}=75 \mu \mathrm{A}$. The distance gap $\mathrm{d}=3 \mathrm{~mm}$. Input and output monochromator spectral slits were of the same value $\Delta \mathrm{l}=0.05 \mathrm{~mm}$. The conditions for recording the spectra did not change during the experiment. The gain of the signal at the DCA was controlled and kept constant, the voltage at the PMT was kept constant, and the noise level at the ADC was also controlled at the beginning and at the end of the measurement of the spectra.

It was found that in the wavelength ranges $200 \ldots .290$ and $510 \ldots 600 \mathrm{~nm}$, no intense spectral lines are observed at a level above the background. In the wavelength range of $290 \ldots 310 \mathrm{~nm}$, there are intense emission lines of the second positive system of molecular nitrogen (transitions $\mathrm{C}^{3} \mathrm{P}_{\mathrm{u}}-\mathrm{B}^{3} \mathrm{P}_{\mathrm{g}}$ ), as well as lines corresponding to the emission of the hydroxyl radical OH. In Fig. 4 below, a part of obtained spectrum in the wavelength range of $290 \ldots 310 \mathrm{~nm}$ is shown.

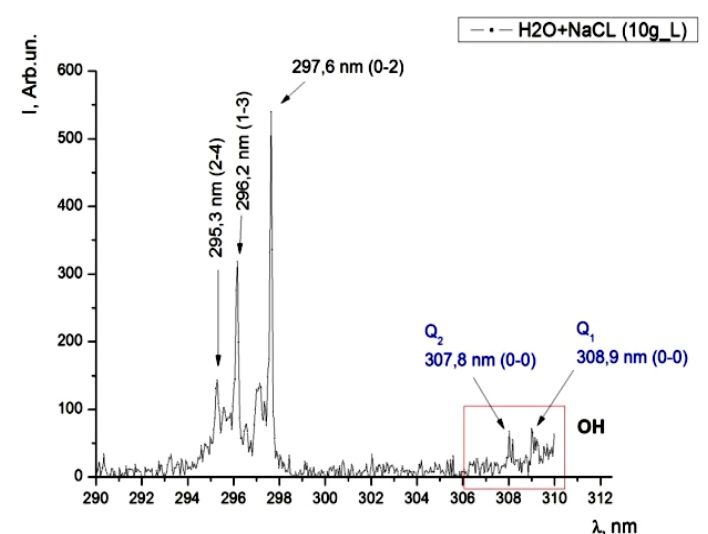

Fig. 4. Emission spectrum of the discharge above the surface of $\mathrm{NaCl}$ aqueous solution. Applied voltage $U=9.5 \mathrm{kV}$, average discharge current $I=75 \mu \mathrm{A}$, discharge gap $d=3 \mathrm{~mm}$

Fig. 5 shows a part of the recorded emission spectrum in the wavelength range of $300 \ldots 410 \mathrm{~nm}$.

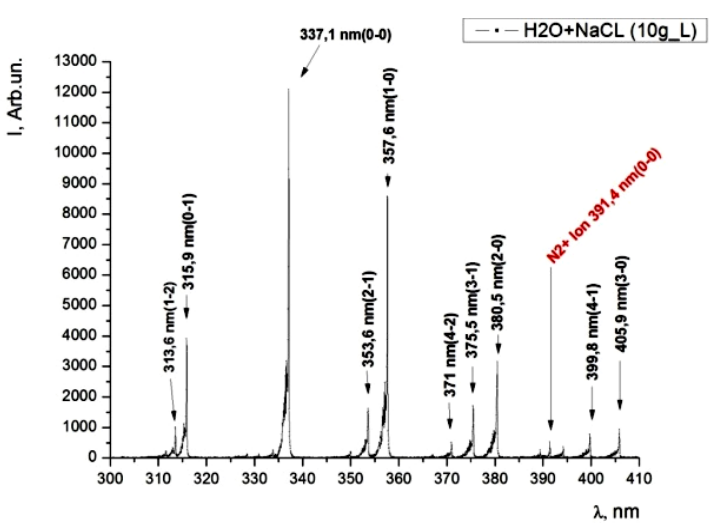

Fig. 5. Emission spectrum of the discharge above the surface of $\mathrm{NaCl}$ aqueous solution.

$$
U=9.5 \mathrm{kV}, I=75 \mu \mathrm{A}, d=3 \mathrm{~mm}
$$

Fig. 6 shows a part of the recorded emission spectrum in the wavelength range of $400 \ldots .510 \mathrm{~nm}$.

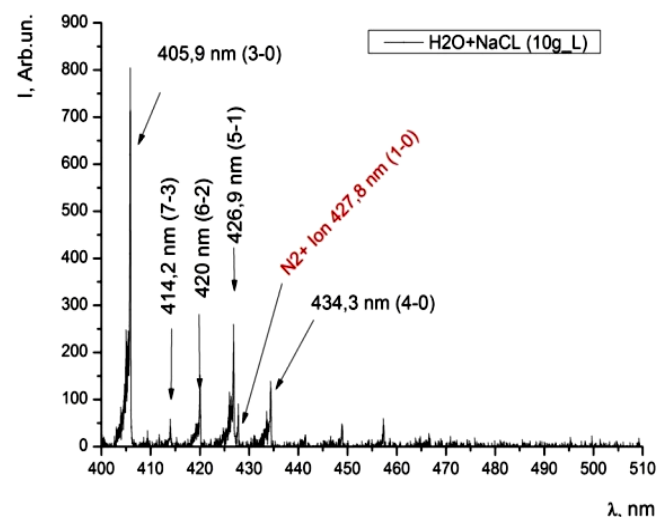

Fig. 6. Emission spectrum of the discharge above the surface of $\mathrm{NaCl}$ aqueous solution. $U=9.5 \mathrm{kV}, I=75 \mu \mathrm{A}, d=3 \mathrm{~mm}$

It can be seen from the above spectra that, along with easily realized emission bands of the second positive system of molecular nitrogen $\mathrm{N}_{2}$, emission of lines corresponding to the molecular nitrogen ion $\mathrm{N}_{2}^{+}\left(\mathrm{B}^{2} \Sigma_{\mathrm{u}}-\right.$ $\mathrm{X}^{2} \Sigma_{\mathrm{g}}$ transitions) is also observed. Among the lines of the molecular nitrogen ion, two lines have high intensity: $391.4 \mathrm{~nm}$ (0-0 transition), and $427.8 \mathrm{~nm}$ (1...0 transition). Also in the emission spectra one can observe the lines of the $\mathrm{OH}$ radical, which are located in the wavelength range of $307 \ldots 309 \mathrm{~nm}$. In particular, it was possible to partially resolve two lines of the $\mathrm{Q}$ branch of the $\mathrm{OH}$ hydroxyl radical, the $\mathrm{A}^{2} \Sigma^{+}-\mathrm{X}^{2} \Pi$ transitions $\left(\mathrm{Q}_{1^{-}}\right.$ $308.9 \mathrm{~nm}(0-0)$ and $\left.\mathrm{Q}_{2}-307.8 \mathrm{~nm}(0-0)\right)$. The presence in spectrum of intense emission lines of ionized particles and free radicals indicates that the discharge has electrons with sufficient energy. It should also be noted that there are no lines in the emission spectra that correspond to the elements of an aqueous solution of $\mathrm{NaCl}$. This indicates that the main processes of excitation and ionization proceed mainly in the active zone of the discharge and involve only the gas phase above the surface of the solution. It is of interest to use this type of discharge for plasma-chemical technologies in which the production of chemically active particles and free radicals is an essential factor. 


\section{CONCLUSIONS}

Due to investigation it was shown that, regardless of the conductivity of aqueous salt solutions, the type of ions, in a fixed discharge gap, the current-voltage characteristics of the discharge are similar. At the same time, at a fixed applied voltage, we can observe similar amplitude-frequency characteristics of Trichel pulses for discharges with liquid anodes of different conductivity. In particular, for distilled water (water conductivity $\mathrm{EC}=1.62 \mu \mathrm{S} / \mathrm{cm})$ and an aqueous solution of cobalt chloride $(\mathrm{EC}=8610 \mu \mathrm{S} / \mathrm{cm})$, a similarity was shown in the current characteristics of the discharge. This may indicate that the conductivity of the solution does not affect the mechanism for establishing the sequence of Trichel current pulses. Also it does not significantly affect the processes occurring in the active and drift zones of the discharge gap. It was shown that the current-voltage characteristics of discharge are in good agreement with the results of theoretical calculations using the Townsend expression. Analysis of the emission spectra from the active zone of discharge in the wavelength range of $200 \ldots 600 \mathrm{~nm}$ has shown that most of the spectral lines corresponded to the emission spectra of the second positive system of molecular nitrogen $\mathrm{N}_{2}$ (transitions $\mathrm{C}^{3} \mathrm{P}_{\mathrm{u}}-\mathrm{B}^{3} \mathrm{P}_{\mathrm{g}}$ ). The emission spectra also have the lines of the molecular nitrogen ion $\mathrm{N}_{2}^{+}\left(\mathrm{B}^{2} \Sigma_{\mathrm{u}}-\right.$ $\mathrm{X}^{2} \Sigma_{\mathrm{g}}$ transitions), where the most intense lines are 391.4 $\mathrm{nm}$ (transition 0-0), and $427.8 \mathrm{~nm}$ (transition 1...0). The spectra also have lines corresponding to the emission of the $\mathrm{OH}$ hydroxyl radical $\left(\mathrm{A}^{2} \Sigma^{+}-\mathrm{X}^{2} \Pi\right.$ transitions $)$. The $\mathrm{OH}$ spectrum has two lines of the $\mathrm{Q}$ branch of the hydroxyl radical band $\left(\mathrm{Q}_{1}-308.9 \mathrm{~nm}(0-0)\right.$ and $\mathrm{Q}_{2}-$ $307.8 \mathrm{~nm}(0-0))$. Respectively, the discharge has electrons with a sufficient energy for generating active particles and free radicals. It can be possible to use this type of discharge for plasma-chemical technologies, in which the generation of chemically active particles and free radicals is a significant factor. It is possible to use this type of discharge for water purification from impurities and disinfection.

\section{REFERENCES}

1. V.I. Golota, L.M. Zavada, B.B. Kadolin. Generatsiya ozona v tleyushchem razryade polozhitel'noy polyarnosti // Problems of Atomic Science and Technology. Seriya «Plazmennaya elektronika i novyye metody uskoreniya» (2). 2000, № 1, p. 58-62 (in Russian).

2. M.A. Malik, A. Ghaffar, S.A. Malik. Water purification by electrical discharges // Plasma Sources Sci. Technol. 2001, № 10, p. 82-91.

3. L.R. Grabowski, E.M. Veldhuizen, A.J.M. Pemen, W.R. Rutgers. Corona above water reactor for systematic study of aqueous phenol degradation // Plasma Chem. Plasma Proc. 2006, № 26, p.3-17.

4. Yu.P. Raizer. Gas Discharge Physics. Berlin: "Springer", 1991.

5. G.W. Trichel. The mechanism of the negative point to plane corona near onset // Physical Review. 1938, v. 54, p. 1078.

6. Y.S. Akishev, M.Ye. Grushin, V.B. Karal'nik, N.I. Trushkin. Pul'siruyushchiy rezhim otritsatel'noy korony v azote // Plasma Physics Reports. 2001, v. 27, p. 550.

7. O.V. Bolotov, V.I. Golota, S.D. Gurtovoi, Y.V. Sitnikova, D.V. Moshinskii. Gas temperature of diffuse negative corona discharge // Problems of Atomic Science and Technology. Series «Plasma Electronics and New Methods of Acceleration» (86). 2013, № 4, p. $229-232$

8. N.A. Kaptsov. Koronnyy razryad. MoskvaLeningrad: "OGIZ”, 1947 (in Russian).

Article received 29.09.2020

\section{СПЕКТРЫ ИЗЛУЧЕНИЯ И ТОКОВЫЕ ХАРАКТЕРИСТИКИ ОТРИЦАТЕЛЬНОГО КОРОННОГО РАЗРЯДА В ЭЛЕКТРОДНОЙ СИСТЕМЕ С ЖИДКИМ АНОДОМ}

\section{О.В. Болотов, В.И. Голота, Г.В. Таран}

Проведены экспериментальные исследования спектров излучения и токовых характеристик отрицательного коронного разряда над поверхностью водных растворов солей. Зарегистрированы и идентифицированы спектры излучения из генерационной зоны разряда в диапазоне длин волн 200...600 нм. Установлено, что большинство спектральных линий соответствует линиям спектров излучения 2-й положительной системы молекулярного азота. Наблюдаются линии молекулярного иона азота и линии, соответствующие излучению гидроксильного радикала ОН в УФ-части спектра. Зарегистрированы ВАХ разряда в нестационарной и диффузной стадиях горения. Показано хорошее соответствие ВАХ результатам теоретического расчета по формуле Таунсенда.

\section{СПЕКТРИ ВИПРОМІНЮВАННЯ І СТРУМОВІ ХАРАКТЕРИСТИКИ НЕГАТИВНОГО КОРОННОГО РОЗРЯДУ В ЕЛЕКТРОДНІЙ СИСТЕМІ 3 РІДКИМ АНОДОМ}

\section{О.В. Болотов, В.І. Голота, Г.В. Таран}

Проведені експериментальні дослідження спектрів випромінювання та струмових характеристик негативного коронного розряду над поверхнею водних розчинів солей. Зареєстровані та ідентифіковані спектри випромінювання з генераційної зони розряду в діапазоні довжин хвиль $20 \ldots 600$ нм. Встановлено, що більшість спектральних ліній відповідає лініям спектрів випромінювання 2-ї позитивної системи молекулярного азоту. Спостерігаються лінії молекулярного іона азоту, і лінії, що відповідають випромінюванню гідроксильного радикала ОН в УФ-області спектра. Зареєстровані ВАХ розряду в нестаціонарній і дифузній стадіях горіння. Показана хороша відповідність ВАХ результатам теоретичного розрахунку за формулою Таунсенда. 